\title{
Age estimation in common sole Solea solea larvae: validation of daily increments and evaluation of a pattern recognition technique
}

\author{
Françoise Lagardère ${ }^{1, *}$, Hervé Troadec ${ }^{2}$ \\ ${ }^{1}$ CREMA-L'Houmeau (CNRS-IFREMER), BP 5, F-17137 L'Houmeau, France \\ ${ }^{2}$ IFREMER, LASAA Centre de Brest, BP 70, F-29280 Plouzané, France
}

\begin{abstract}
Close similarities have been found between the otoliths of sea-caught and laboratoryreared larvae of the common sole Solea solea (L.), given appropriate temperatures and nourishment of the latter. But from hatching to mouth formation, and during metamorphosis, sole otoliths have proven difficult to read because the increments may be less regular and low contrast. In this study, the growth increments in otoliths of larvae reared at $12^{\circ} \mathrm{C}$ were counted by light microscopy to test the hypothesis of daily deposition, with some results verified using scanning electron microscopy (SEM), and by image analysis in order to compare the reliability of the 2 methods in age estimation. Age was first estimated (in days posthatch) from light micrographs of whole mounted otoliths. Counts were initiated from the increment formed at the time of mouth opening (Day 4). The average incremental deposition rate was consistent with the daily hypothesis. However, the light-micrograph readings tended to underestimate the mean ages of the larvae. Errors were probably associated with the low-contrast increments: those deposited after the mouth formation during the transition to first feeding, and those deposited from the onset of eye migration (about $20 \mathrm{~d}$ posthatch) during metamorphosis. SEM failed to resolve these lowcontrast areas accurately because of poor etching. A method using image analysis was applied to a subsample of micrograph-counted otoliths. The image analysis was supported by an algorithm of pattern recognition (Growth Demodulation Algorithm, GDA). On each otolith, the GDA method integrated the growth pattern of these larval otoliths to averaged data from different radial profiles, in order to demodulate the exponential trend of the signal before spectral analysis (Fast Fourier Transformation, FFT). This second method both allowed more precise designation of increments, particularly for low-contrast areas, and more accurate readings but increased error in mean age estimation. The variability is probably due to a still rough perception of otolith increments by the GDA method, counting being achieved through a theoretical exponential pattern and mean estimates being given by FFT. Although this error variability was greater than expected, the method provides for improvement in both speed and accuracy in otolith readings.
\end{abstract}

KEY WORDS: Larval sole $\cdot$ Solea solea $\cdot$ Otolith $\cdot$ Daily increment $\cdot$ Validation $\cdot$ Image analysis

\section{INTRODUCTION}

Laboratory and field studies using different methods for estimating daily growth increments in larval fish have provided the basis for the present study. The spatial and temporal distribution of the eggs and larvae of the common sole Solea solea (L.) was investigated across the French part of the Bay of Biscay shelf (Koutsikopoulos 1991, Koutsikopoulos et al. 1991, Amara et

•E-mail: flagarde@ifremer.fr al. 1993, 1994, Amara 1995) to determine processes governing survival of the pelagic stages and estuarine colonisation. Ages of sole larvae sampled at sea were directly estimated from counts of otolith increments [defined as bipartite structures consisting of contiguous light (L-) and dark (D-) zones, otolith terminology according to Kalish et al. (1995)]. In support of field studies, Lagardère \& Chaumillon (1988), Lagardère \& Troadec (1992), and Boulhic et al. (1992) found evidence of close similarities between otoliths from the wild and otoliths of larvae reared at $12^{\circ} \mathrm{C}$, which included 'checks' and areas of poorly defined increments. 
These areas were similar to those described in studies done on other fish species, for example by Rice et al. (1985) and Maillet \& Checkley (1989) for increments deposited in the central area of otoliths, or by Jenkins \& Davis (1990) for increments deposited near the edge of larger otoliths. Experiments have been designed to study the effect of starvation, low temperature and darkness on otolith structure (Lagardère $\&$ Chaumillon 1988, Lagardère 1989). They indicated that the 2 innermost 'checks' are concomitant with 2 ontogenetic events, hatching $(\mathrm{H})$ and mouth opening $(\mathrm{M})$, and that $\mathrm{M}$ is deposited on 1 day (Day 4 at $12^{\circ} \mathrm{C}$ ), independent of feeding conditions. By contrast, the poorly defined increments which follow $\mathrm{M}$ formation were shown to depend on larval growth at the first-feeding (FF) stage. Poor first-feeding conditions enlarged the FF area concerned by those poorly defined increments, compared to controls receiving an appropriate nourishment. Therefore, $\mathrm{M}$ can be used as a reliable benchmark to initiate counts (Troadec 1991, Lagardère \& Troadec 1992) for laboratory-reared larvae. The method for dating the $\mathrm{M}$ formation for sea-caught larvae was taken from Fonds' (1979) models which predict duration of the embryonic stage as a function of the rearing temperature (Koutsikopoulos et al. 1991, Boulhic et al. 1992, Amara et al. 1993, 1994, Amara 1995).

It is generally agreed that, even after a perinuclear area of poor definition caused by extreme first-feeding conditions (Laroche et al. 1982, Campana et al. 1987, Jenkins 1987, Siegfried \& Weinstein 1989), the formation of daily increments in otoliths of larval fish tends to be regular (reviews by Campana \& Neilson 1985, Jones 1992). It should be noted that there are exceptions, when depositions occur more often than once in $24 \mathrm{~h}$ as they often do in sagittal otoliths at the late larval or juvenile stage (Geffen 1982, McGurk 1987, Campana 1992, Szedlmayer \& Able 1992). Experiments have shown that these sub-daily increments can be induced by temperature and feeding manipulations (Neilson \& Geen 1982). Low-contrast increments have been extensively documented because they are associated with ageing errors, whether they are concerned with the narrow and faint increments of the firstfeeding stage (FF transition), or with the daily and subdaily increments of the metamorphosis transition zone (TZ) (Rice et al. 1985, Campana et al. 1987, Rice 1987. Campana \& Moksness 1991).

Ageing errors occur because of the obvious difficulty in detecting and counting small increments even using scanning electron microscopy (SEM) (e.g. Jones \& Brothers 1987) and, with greater reason, when observing low-contrast increments through an optical microscope. In this case, often observed in slow-growing larvae, errors occur because the L-zones still grow and 'create apparent non-daily increments' (Hare \& Cowen
1994) while the D-zones are too faint to be resolved by light microscopy. The errors can come from what is expected of otolithic structure, depending on larval growth rate, or on the appearance of the increments, especially with regard to the distinction between daily and sub-daily increments. Errors in 'reading' otoliths can also come from the preparation of the samples, from the microscope resolution, or from implicit bias factors, such as previous knowledge of the samples (Campana \& Moksness 1991, Neilson 1992). Similar indistinct increments, deposited during first-feeding and metamorphosis, have frequently been observed in otoliths of both wild and laboratory-reared larvae (Boulhic et al. 1992, Lagardère \& Troadec 1992), and it is clear that a more reliable way to count them is needed.

Attempting to find a more objective way to count all otolith increments, including those from the lowcontrast areas, we developed a pattern recognition technique and tested it under the double constraint of a known age at the initiation of counts (at the $M$ 'check') and of a 1-phased model fitting expected otolith growth to age (Lagardère 1989, Troadec 1991). To assess the reliability of age estimates given by each of the 2 methods, we had to validate the hypothesis of daily increments with known larval ages and compare the estimates obtained by direct visual counts to those obtained by semi-automated image analysis, according to validation criteria (Beamish \& McFarlane 1983, Rice 1987, Geffen 1992, Francis 1995).

\section{MATERIAL AND METHODS}

Larval rearing, sampling and survival. Larvae were produced as previously described (Lagardère 1989, Boulhic et al. 1992), in the IFREMER laboratory, Brest, France, in March and April 1987, providing us with larvae reared at $12^{\circ} \mathrm{C}$ used for 'check' validation (Lagardère \& Chaumillon 1988, Lagardère 1989) and for this study. Eggs were spawned naturally by captive sole and incubated at $13^{\circ} \mathrm{C}$ for $4 \mathrm{~d}$. All hatching occurred during a period of $24 \mathrm{~h}$ and Day 0, defined as starting when $50 \%$ of the larvae had hatched, thus varied by $\pm 12 \mathrm{~h}$ within the group of experimental larvae. Ages and further estimates are given in days posthatch.

After hatching, yolk-sac larvae were transferred into 2 cylindro-conical tanks (tanks A and B; Table 1), each $2250 \mathrm{l}$ in volume, in which the water was circulated. They were incubated at $11^{\circ} \mathrm{C}$, increasing to $12 \pm 0.6^{\circ} \mathrm{C}$ after a few days, the upper limit of seawater temperatures in the Bay of Biscay during the spawning season (winter and early spring: Arbault et al. 1986). Salinity was maintained in the 34 to $35 \mathrm{ppt}$ range and oxygen at 
Table 1. Solea solea. Sample size of laboratory-reared sole larvae (N1) and otolith readings ( $\mathrm{N} 2$ ) for age estimates, given as mean count +3 (SD: standard deviation; CV: coefficient of variation)

\begin{tabular}{|cccccccc|}
\hline \multirow{2}{*}{$\begin{array}{c}\text { True age } \\
\text { (d) }\end{array}$} & \multicolumn{3}{c}{ Larval sampling } & \multicolumn{3}{c|}{ Otolith readings (counts + 3) } \\
& Tank A & Tank B & N1 & N2 & Mean & SD & CV $(\%)$ \\
\hline 1 & 6 & - & 6 & - & - & - & - \\
2 & 6 & - & 6 & - & - & - & - \\
3 & 6 & - & 6 & - & - & - & - \\
4 & 10 & - & 10 & 10 & 4.0 & 0 & 0 \\
5 & 10 & - & 10 & 10 & 4.4 & 0.52 & 11.7 \\
6 & 10 & - & 10 & 10 & 5.3 & 1.16 & 21.9 \\
8 & 10 & 1 & 11 & 9 & 7.4 & 1.13 & 15.2 \\
9 & & 1 & 1 & 1 & 9 & - & - \\
10 & 10 & 2 & 12 & 9 & 9.7 & 0.90 & 9.3 \\
11 & & 1 & 1 & 1 & 11 & - & - \\
12 & 10 & 1 & 11 & 11 & 11.1 & 1.18 & 10.6 \\
14 & 10 & 2 & 12 & 12 & 14.1 & 0.80 & 5.7 \\
16 & 10 & 3 & 13 & 13 & 15.7 & 1.27 & 8.1 \\
18 & 10 & 2 & 12 & 12 & 17.7 & 1.18 & 6.6 \\
20 & 10 & 1 & 11 & 11 & 19.5 & 0.93 & 4.8 \\
22 & 10 & 2 & 12 & 12 & 21.4 & 0.93 & 4.4 \\
24 & 10 & 3 & 13 & 13 & 23.7 & 0.86 & 3.6 \\
26 & 10 & 3 & 13 & 13 & 25.7 & 1.09 & 4.2 \\
28 & 10 & 3 & 13 & 13 & 28.0 & 1.11 & 4.0 \\
30 & 9 & 5 & 14 & 10 & 30.6 & 1.17 & 3.8 \\
Total & 167 & 30 & 197 & 170 & & & \\
& & & & & & & \\
\hline
\end{tabular}

Table 2. The intake of food was observed from Day 5 for most of the larvae (Lagardère 1989). The yolk-sac supplies were exhausted on Day 9 (Boulhic 1991).

Otoliths (sagitta, lapillus and asteriscus, when present), were extracted from their otic capsule. An attempt was made to separate right from left otoliths in most cases and sagittae from lapilli for the early stages. Otoliths were mounted whole in Permount on ultrathin cover-slips $(0.15 \mathrm{~mm})$, their proximal surface downside. Their transparency and shape allowed examination without further preparation. Each cover-slip was afterwards taped to a metallic support, the drop of mounting medium on the underside. Preparations were coded for blind readings and otoliths were viewed under Leitz compound microscopes by transmitted light. Magnification was varied from $\times 500$ to $\times 1250$ to take micrographs or process image analysis
90 to $95 \%$ saturation. Light was supplied by fluorescent tubes, with a power of $8.48 \mathrm{~W} \mathrm{~m}^{-2}$ at the surface of the tanks and constant photoperiod (light:dark 18:6 h). Larvae were provided with Artemia nauplii and food was offered as soon as the mouth opened, i.e. at Day 4, in order to obtain optimal feeding conditions. Dead larvae were removed from the tanks every day. The experiment terminated on Day 30.

Samples of 6 to 10 larvae $\operatorname{tank}^{-1} \mathrm{~d}^{-1}$ were taken during the early stages and on alternate days for the later stages. They were preserved and stored in $95 \%$ ethyl alcohol before analysis. Corrected for samples taken during the experiment, survival at the end of the experiment was estimated at 60 to $80 \%$ (Lagardère 1989). The overall samples comprised all larval ages, with approximately 10 individuals per age class taken from tank $A(N=167)$, except for some larvae $(\mathrm{N}=30)$ taken from tank B to compensate for losses during preparation or discarded specimens and, later, to increase the sample size of some age classes $(\mathrm{N} 1=197$; Table 1).

Microscopic examination of larvae and otoliths. Larvae were measured at standard lengths (SL, $\pm 0.1 \mathrm{~mm}$ ) and staged according to Al-Maghazachi \& Gibson (1984) for turbot Scophthalmus maximus, modified for sole as given in and, in this case, to obtain a full screen otolith. The use of a Planapoachromat objective, with immersion oil, to reach a magnification of $\times 1250$ led us to expect a resolving power at least as good as $0.5 \mu \mathrm{m}$.

Light microscope and SEM analyses. Sagittae were measured for perpendicular axes and the mean radius (mean diameter/2) was calculated, as well as the mean diameter \pm SE of 2 landmarks [15.6 \pm 0.16 and $26.7 \pm$ $0.22 \mu \mathrm{m}$ for hatch $(\mathrm{H})$ and mouth-opening $(\mathrm{M})$ 'checks', respectively; Lagardère 1989]. To make up for the lack of a video system when this study started, otoliths were photographed for increment counts (routine readings
Table 2. Solea solea. Life intervals for sole, from hatching to newly settled late larvae and early juveniles (stages according to Al-Maghazachi \& Gibson 1984)

$\left.\begin{array}{|cr|}\hline \text { Period } & \text { Stage } \\ \hline \text { Embryonic } & 1 \\ \text { Larval pelagic } & 3\end{array}\right]$ Transition to first feeding (FF)


or reader counts) using a monochromatic green filter $(546 \mathrm{~nm})$. Small specimens were photographed as a whole, while several micrographs were taken, adjusting the focus to the observed area (nuclear area or margin) for large otoliths. Counts were initiated from $M$ (Day 4), and the mean counts +3 used as estimated age $(\mathrm{N} 2=170)$. Counts were made along the best radial area of the 2 sagittae and repeated if necessary to resolve differences between left and right. Otoliths were discarded if unsuitable for examination (unclear microstructure due to preservation or mounting procedure) or in the case of a disagreement greater than \pm 2 between left and right sagittae. This concerned 5\% of the larvae, mostly early or metamorphosing stages ( 8 to 10 or $30 \mathrm{~d}$ old larvae; Table 1).

Due to a lack of resolution under light microscopy, low-contrast increments were investigated using SEM in $30 \mathrm{~d}$ old larvae $(N=10)$. Sagittae were mounted on stubs, polished, etched with 0.1 M EDTA ( $\mathrm{pH} 7.6$ ) and coated with gold for SEM examination, following the procedure of Karakiri \& von Westernhagen (1988).

Image analysis and the growth demodulation algorithm (GDA). A subsample ( $\mathrm{N}=40$ ) of light microscope preparations was taken at random for blind readings to compare age estimates obtained from image analysis with estimates obtained by counts from micrographs. Owing to the small subsample size, results were merged into age classes of $6 \mathrm{~d}$ for statistical analysis.

The pattern recognition technique is based on the increment structure, basically defined by the sequence of light (L-) and dark (D-) zones. The width distribution of increments is structured by an overall phenomenon linked to the otolith growth pattern (Fig. 1A). The sequence of L- and D-zones produces a waveform whose frequency depends on the growth pattern. Since the growth pattern can be described, it can be substracted from the signal by an anamorphosis (currently used with log-transform) which corresponds to a frequency demodulation (Fig. 1B). Once the signal is demodulated, the mean number of increments can be estimated by spectrum analysis, using a global method, contrary to the counting of increments one by one, which we consider a local method.

Digital images were first processed in polar coordinates as described by Troadec (1991) with the TNPC software (Traitement Numérique de Pièces Calcifiées). Owing to irregular image definition, this processing was not reduced to a single radial profile $R$, but ex- tended over a region of interest by an average radial profile (Troadec \& Prouzet 1986, Troadec 1991, Welleman \& Storbeck 1995), $R_{\theta}$, which integrates the information about the image $I$ at a fixed radius, $r$, over the $n$ angular values:

$$
R_{\theta}=\underset{i=1, \ldots, n}{\operatorname{Mean}}\left[I\left(r, \theta_{i}\right)\right]
$$

where $I$ is the digital image, $r$ the radius and $\theta_{i}$ the $i$ th radial angle. In the case of sole otolith larvae, $n$ was fixed at 5 radial profiles with an angular pitch of $2^{\circ}$.

The originality of the method is based on the introduction of an a priori growth pattern to demodulate the real biological signal, i.e. the increment sequences under the particular circumstances. Using an exponential and 1-phased model fitting otolith growth, this processing is conducted to subtract the nonlinearity of the increment size, i.e. to produce a demodulated periodic signal. The otolith growth is represented by:

$$
L_{t}=L_{0} \times \mathrm{e}^{K t}
$$

where $L_{t}$ is the length of otolith at time $t_{1} L_{0}$, otolith length at time $t_{0}$, and $K$ a growth coefficient. The signal is then demodulated by the reciprocal function of Eq. (2):

$$
t=\ln \left(\frac{L_{t}}{L_{0}}\right) / K
$$

Parameters required by the growth model are restricted to the $L_{0}$ value (i.e. otolith size where counts 
are initiated, in this case the radius at mouth opening). As $K$ is only a scale factor in the reciprocal function (Eq. 3) and Fast Fourier Transformation (FFT) produces relative frequencies, no presupposed value of $K$ is required. Once the age has been estimated, $K$ values can be individually back-calculated (Lagardère \& Troadec 1992) from Eq. (2) by:

$$
K=\frac{\ln \left(L_{t} / L_{0}\right)}{t}
$$

Thereafter, demodulation of radial profiles allows recourse to spectral analysis, such as FFT, which is based on a decomposition of signal variance according to frequencies. The signal is seen as a composition of periodic basic signals, each defined by an amplitude which contributes to the overall signal. The mean increment number is estimated as the inverse of the maximum amplitude frequency. As the signal was previously demodulated, low-contrast increments are estimated linearly both on the basis of a pattern of well-contrasted increments of $\mathrm{L}$ - and D-zones and on the basis of the constraints described above, especially the growth pattern. Fig. 1B illustrates the estimated overall increment on an averaged radial profile derived by means of an FFT and shows a significant improvement of the processing, particularly when the biological signal provides scarce information.

The Growth Demodulation Algorithm (GDA) may be described as follows:

(1) Extraction of each basic radial profile, $R_{\theta_{1}}$

(2) Edge detection on each radial profile, $E\left(R_{\theta_{i}}\right)$

(3) Synchronization of the radial profile

(4) Computation of the median radial profile, $R_{\theta}$

(5) Demodulation by the a priori growth pattern

(6) Fourier spectrum computation (FFT)

(7) Detection of the major peak = Increment number estimation (semi-automated readings, GDA counts or operator counts, by contrast with reader counts),

(8) Age = Estimated increment number (GDA counts) $+3$

\section{RESULTS}

\section{Morphology and microstructure of sole otoliths}

From embryos to larvae, sole develop 3 pairs of otoliths (Fig. 2a). The sagittae and lapilli are initiated in embryos and the third pair of otoliths (asterisci) initiated at the beginning of urostylar torsion (early stage 4), i.e. from Day 20 in this experiment. While asterisci were irregular in shape and produced increments that could not be related to a daily pattern, sagittae and lapilli generally had clear, round features. The lapilli were slightly larger than the sagittae before the onset of exogenous feeding, but the sagittal increments quickly became wider than the lapillar ones and were easier to use for larval ageing.

A few hours after hatching, the primordia finished fusing together (Fig. 2b) showing the hatch 'check' (Fig. $2 \mathrm{~d}-\mathrm{f}$ ), which delimited the nucleus $(\mathrm{N})$, also referred to as the core (Kalish et al. 1995). Multiple primordia, often noted in the nucleus of lapilli, also existed in some sagittae of both laboratory-reared (Fig. 2b) and sea-sampled larvae (Fig. 2f). They generated an irregular nuclear outline, making radial-profile measurements more variable. There were no other visible increments inside this benchmark to indicate Day 0. Furthermore, there were no clear perinuclear increments before deposition of the first well-contrasted, daily increment ( $d_{i}$ Fig. 2d-f), except the mouth-opening 'check' (M; Fig. 2d-f). During this short period of adjustment to active feeding, some faint increments were sometimes discernible from $M$ to $d$ (Fig. 2d).

The initiation of uninterrupted formation of increments followed the first intake of food, just before the yolk sac depleted. With the beginning of metamorphosis (onset of eye migration about $20 \mathrm{~d}$ from hatching), the appearance of sagittal increments was gradually modified. Increments became progressively wider but poorly contrasted and included multiple D-zones. From the late stage 4 , asymmetry appeared in the otoliths, with anteroposterior and dorso-ventral axes (Fig. 2a, c). At the end of the experiment (Day 30), the first accessory nuclei (an; Fig. 2a) were observed in the sagittae of the most developed, settled larvae (late stage 5). Therefore, the zone of wide low-contrast increments and accessory nuclei have both been related to the metamorphosis transition zone. However, at Day 30 most of the larvae were still in early stage 5 and their otoliths presented only the innermost part of this transition zone (TZ; Fig. 2d).

SEM examination confirmed the microstructural features of the perinuclear area, with a prominent discontinuous zone (M; Fig. 3d) whose measurement indicated deposition at the mouth-opening stage, followed by a poorly etched zone where the daily increments, if they existed, were unresolved. Once clear increments were deposited, they were $>1 \mu \mathrm{m}$ in width, reaching 3 to $5 \mu \mathrm{m}$ in the innermost part of the metamorphosis transition zone (TZ; Fig. 3b). The wide increments of this zone had etching characteristics which made it difficult to distinguish between daily and sub-daily increments (Fig. 3e). Accessory nuclei were frequently located at the extremity of radial discontinuities (an; Fig. 3a).

\section{Larval and sagittal growth}

Relationships between the main microstructural features of sole otoliths and the main ontogenetic events 


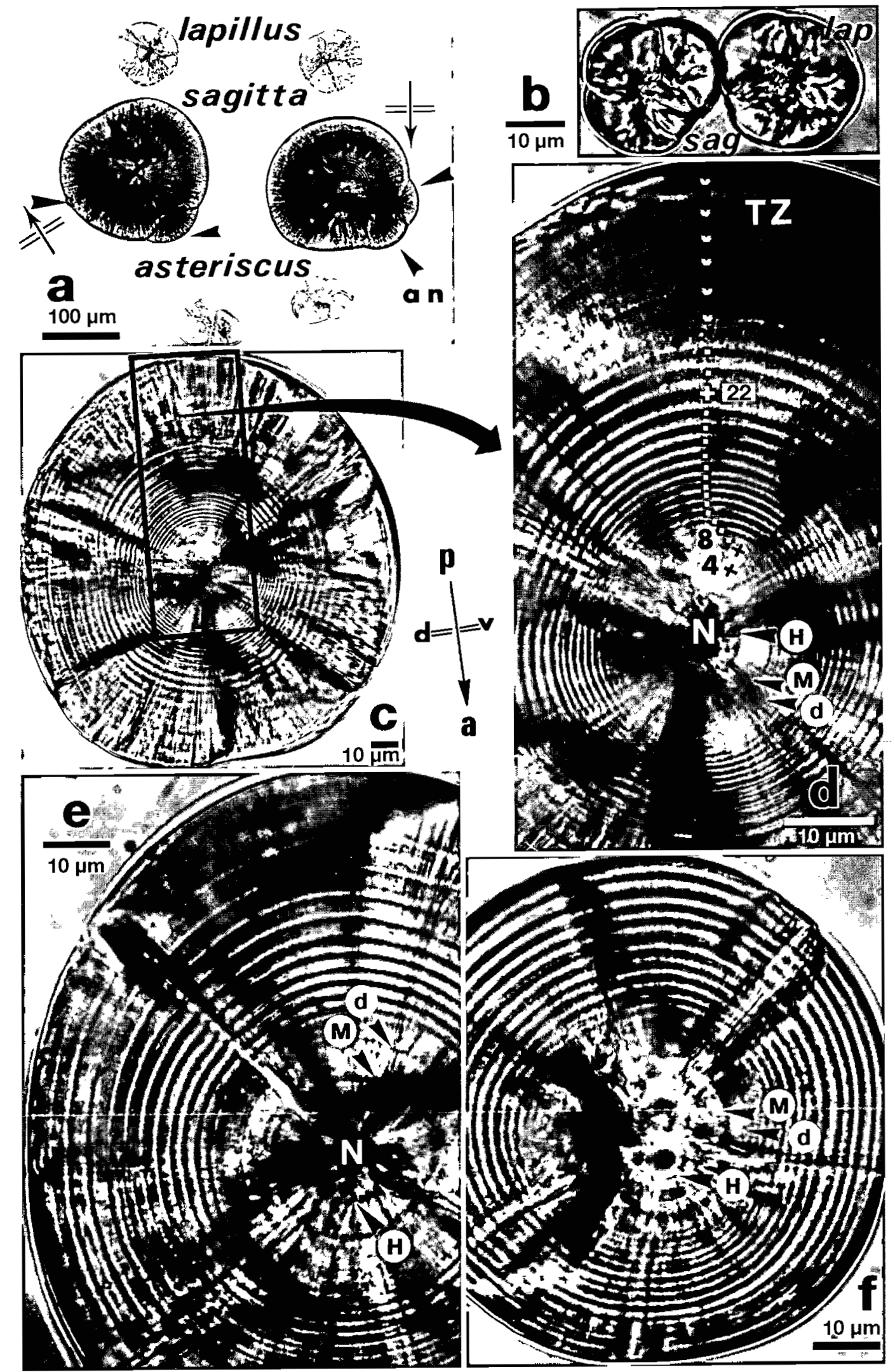


Fig. 2. Solea solea. Light micrographs of (a to e) sole larval otoliths from $12^{\circ} \mathrm{C}$ laboratory experiments (a to e), compared with (f) an otolith from a larva sampled at sea. (a) Otoliths of a fast-growing $30 \mathrm{~d}$ old larva, with indication of the orientation axes (crossed arrows) and accessory nuclei (an) of the sagittae. (b) Sagitta (sag) and lapillus (lap) of a 1d old larva (note multiple primordia). (c) Sagitta of a slow-growing 30 d old larva. (d) Insel of (c) at higher magnification showing the nucleus (N) delimited by the hatch check $(\mathrm{H})$, the perinuclear area with dated increments at mouth opening $(\mathrm{M})$ and initiation of uninterrupted daily increments (d), respectively, and the metamorphosis transition zone (TZ). (e) Sagitta of a $22 \mathrm{~d}$ old larva with the same innermost microstructures. (f) Sagitta of an estimated 22 d old larva sampled at sea (note the same innermost microstructures, including multiple primordia as in b)

of larval growth are given in Fig. 4, with shaded areas to indicate transition zones deposited during the first-feeding stage (FF area) and metamorphosis (TZ). Growth equations, recalculated from Lagardère's (1989) data for standard length (SL) and sagittal radius (RAD) for up to $30 \mathrm{~d}$, were respectively:

$$
\begin{array}{ll}
\mathrm{SL}=3.94 \mathrm{e}^{0.034 t} & \left(\mathrm{~N}=197, \mathrm{R}^{2}=0.967\right) \\
\mathrm{RAD}=10.47 \mathrm{e}^{0.073 t} & \left(\mathrm{~N}=197, \mathrm{R}^{2}=0.991\right)
\end{array}
$$

where $t$ is the age in days posthatch. Slow-growing larvae, outside the $95 \%$ confidence interval (small arrows, Fig. 4), could be identified from both larval and sagittal parameters. They probably survived unfavourable first-feeding conditions and increased the variability of the data. An inset of this graph (Fig. 4, 'Perinuclear area') shows that there was no cessation of otolith growth from hatching, $\mathrm{H}$, to first feeding, FF, but there was a discrepancy between the otolith model and the observations, which was due, at least in part, to rearing temperatures lowered from $13^{\circ} \mathrm{C}$ to $11^{\circ} \mathrm{C}$. Accordingly, both the microstructural features of the perinuclear area and the pattern of early otolith growth led us to set $L_{0}$ in Eq. (2) as equal to the value of the M 'check' (Fig. 4), rather than to that of the hatch 'check', in computing average radial profile data.

\section{Reader age estimation}

Mean ages estimated by the reader are presented in Table 1 . The relationships between estimated age and real age, fitted to linear regressions, are given in
Table 3. The regression parameters were tested (Student's $t$-test) to verify the coherence of the reading method with the hypothesis of a deposition rate not significantly different from 1 increment $\mathrm{d}^{-1}\left(\mathrm{H}_{0}\right.$ : slope $=1$ ). The null hypothesis for a slope of 1.0 was not rejected ( $t=1.895$ not significant for $\mathrm{df}=169, \mathrm{p}>0.05$ ) and the power of the test, for a deviation of 0.1 from a slope of 1.0 (Rice 1987), was estimated as 0.99 . The overall precision of age determination was estimated by inverse regression (Rice 1987) to within $\pm 2 \mathrm{~d}$.

Individual errors were calculated from true ages and the normality of error distribution was confirmed by the Kolmogorov-Smirnov test. A Student's $t$-test on the mean error, $\mu=-0.30 \mathrm{~d}, \sigma=1.018$, showed a slight tendency of the method to underestimate the true age $\left(\mathrm{H}_{0}: \mu=0\right.$, not rejected for $t=3.79, \mathrm{p}=0.45$, df $\left.=169\right)$, although counts might have included increments deposited from $M$ to $d$ when they were sufficiently visible. The graph of mean errors of age (Fig. 5A) confirms this tendency for the reader to underestimate the mean age by about $0.3 \mathrm{~d}$, taking the larval period as a whole. The lack of error on $4 \mathrm{~d}$ old larvae is explained by all counts starting with the $M$ 'check' which, by definition, equals Day 4. In early larvae, underestimation coincided with deposition of low-contrast increments in the FF area, furthermore partly obscured by optical artefacts from the margin. These characteristics induced a $21 \%$ rejection rate in the samples from Day 8 to 10 (Table 1). Underestimated ages also occurred in the later stages, probably because some of the innermost increments became overlaid by additional material. In the $30 \mathrm{~d}$ class, however, overestimated ages led to the

\begin{tabular}{|c|c|c|c|c|c|c|c|c|}
\hline \multirow{2}{*}{\multicolumn{2}{|c|}{$\begin{array}{l}\text { Regression model } \\
\text { (estimate }=a+b \text { age) }\end{array}$}} & \multirow{2}{*}{$\begin{array}{l}\mathrm{R}^{2} \\
(\%)\end{array}$} & & \multicolumn{2}{|c|}{ Intercept (a) } & \multicolumn{2}{|c|}{ Slope $(b)$} & \multirow[t]{2}{*}{ Power } \\
\hline & & & & Estimate & SE & Estimate & $\mathrm{SE}$ & \\
\hline \multicolumn{9}{|l|}{ Whole sample } \\
\hline Reader counts +3 & $(\mathrm{~N}=170)$ & 98.6 & & $-0.60(\cdots)$ & 0.178 & 1.018 (NS) & 0.0095 & 0.99 \\
\hline \multicolumn{9}{|l|}{ Sub-sample } \\
\hline Reader counts +3 & $(N=40)$ & 97.6 & & 0.86 (NS) & 0.553 & 0.979 (NS) & 0.0248 & 0.98 \\
\hline GDA counts + 3 & $(\mathrm{~N}=40)$ & 94.0 & $\cdots$ & -0.13 (NS) & 0.927 & 1.014 (NS) & 0.0416 & 0.67 \\
\hline
\end{tabular}

Table 3. Solea solea. Correlation and significance of estimated age versus real age in larval sole reared in the laboratory at $12^{\circ} \mathrm{C}$ (** deviation from $\mathrm{H}_{0}: a=0, b=1$ at $\alpha=0.001$; NS: a non-significant deviation at $\left.\alpha=0.05\right)$. Power is estimated from the test of the slope with a type I error, $\alpha=0.05$, and a slope deviation from $\mathrm{H}_{0,} g=0.1$. SE: standard error 


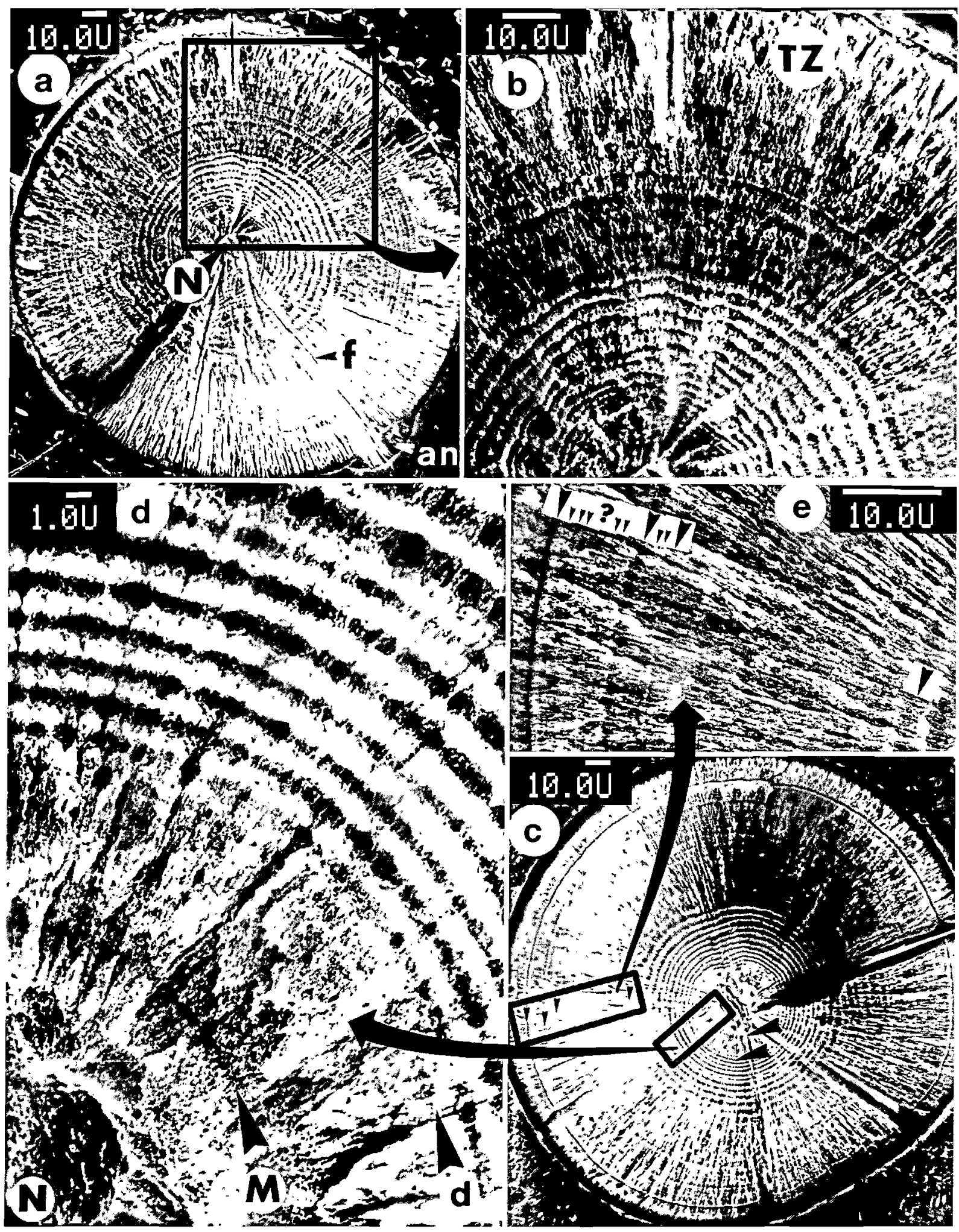

Fig. 3. Solea solea. Scanning electron micrographs of otoliths of $30 \mathrm{~d}$ old sole larvae reared at $12^{\circ} \mathrm{C}$. (a) Note the nuclear area (N) and the positioning of an accessory nucleus (an) at the end of a radial fracture (f). (b) lnset of (a) showing the poorly etched metamorphosis transition zone (TZ). (c) Overview for insets (d) and (e). (d) Nuclear area (N) and poorly etched area between the mouth-opening check (M) and the first uninterrupted daily increments (d). (e) Daily (large arrows and question mark) and sub-daily increments (small arrows) of the metamorphosis transition zone 
Fig. 4. Solea solea. Diagram of relationships between the sagittal microstructures of sole larvae reared at $12^{\circ} \mathrm{C}$ and the somatic and otolith growth curves. Shaded areas correspond to low-contrast zones of first feeding (FF) and metamorphosis (TZ); other abreviations as in Figs. 2 \& 3. Numbered triangles give the beginning of larval stages: (1) yolk sac, (2) primordial fin, (3) fin differentiation, (4) urostylar torsion and (5) transformation. Small arrows indicate slow-growing specimens. Perinuclear area: inset, showing the discrepancy between the data (points and solid line) and the model (o) till the mouth-opening check (M) or $L_{0}$ of image analysis

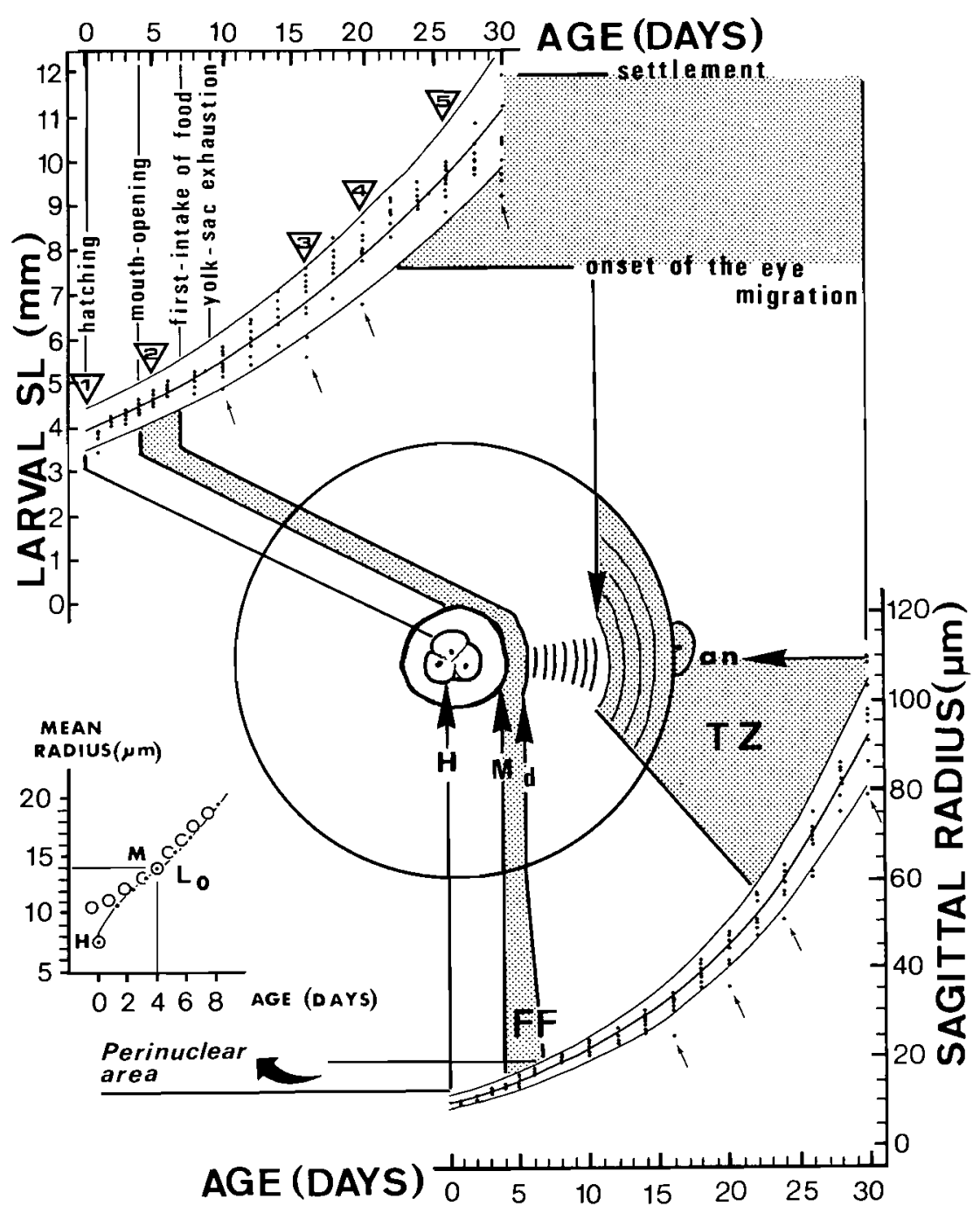

estimates from the same subsample (Tables $3 \& 4$ ). The test of the relationship between true age and estimated age (Table 3 ) showed strong correlation for both the ageing methods (true age/reader estimation, $\mathrm{R}^{2}=$ $97.6 \%$; true age/GDA estimation, $\mathrm{R}^{2}=94.0 \%$ ). The null hypothesis for a slope $=1.0$ was not rejected by a Student's $t$-test for the GDA estimates $(t=0.0075, \mathrm{df}=$ $38, \mathrm{p}>0.05$, power $=0.67$ ) and the precision of ages obtained by GDA counts was estimated by inverse regression to within $\pm 3 \mathrm{~d}$. The same test made on reader counts of the same set of subsamples was consistent with the previous results on the overall sample $(t=0.0191, \mathrm{df}=38, \mathrm{p}>0.05$, power $=0.98)$, with a precision estimated within $\pm 2 \mathrm{~d}$. There was a strong correlation between the 2 ageing methods $\left(R^{2}=91.9\right.$, slope $=1.055 \pm 0.004$, intercept $=-1.444$ ) .

Reading errors were analysed for the discrepancy between age estimation and true age to determine the accuracy and precision of each method (Table 4 ,
Age estimates obtained by the GDA method on a subsample of 40 otoliths were compared with reader 


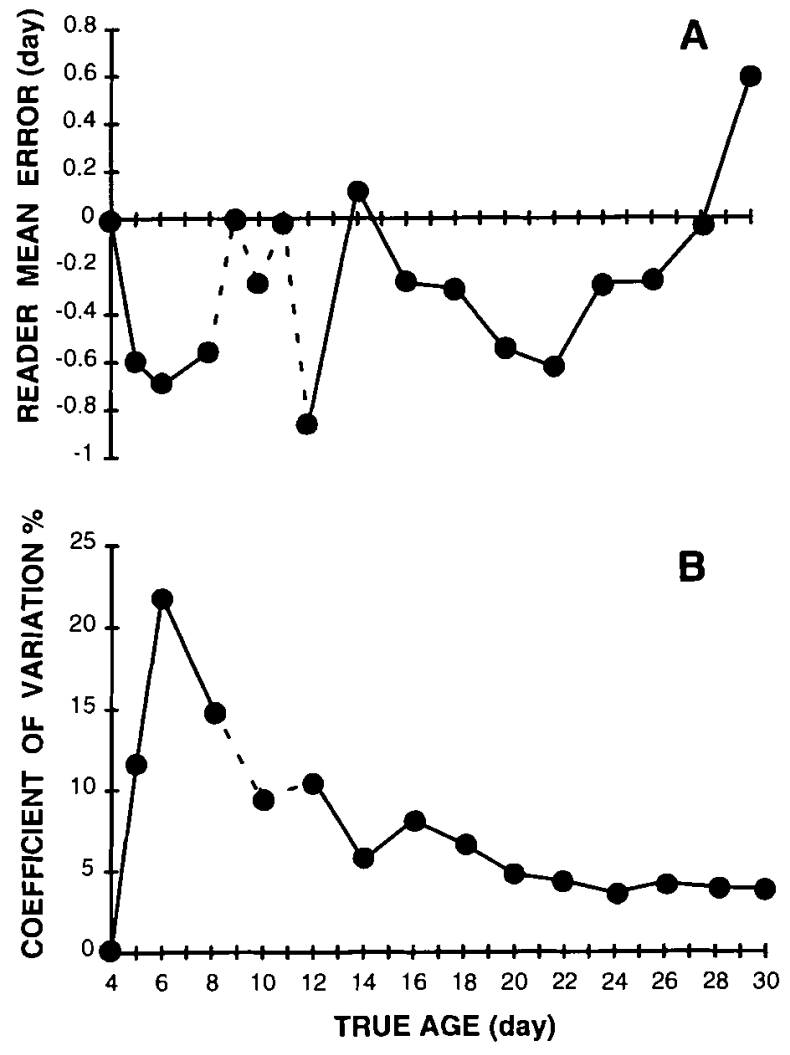

Fig. 5. Solea solea. Graph of reader errors versus true age on the whole sample $(N=170)$; dashed lines are used when there were low numbers or when no estimate of variance was possible. (A) Mean error distribution. (B) Coefficient of variation

Fig. 6). The normality of error distribution linked to subsample readings was confirmed by the Kolmogorov-Smirnov test for both reader and GDA methods. The mean was significantly different from zero for reader errors $(\mu=0.41, \sigma=1.031, t=2.53, \mathrm{df}=39, \mathrm{p}=$ 0.015 ) but not significantly different from zero for GDA errors $(\mu=0.17, \sigma=1.716, t=0.626, \mathrm{df}=39, \mathrm{p}=0.53)$. Application of Student's $t$-test (paired samples) to comparison of the mean $\left(\mathrm{H}_{0}: \mu 1=\mu 2\right)$ showed no significant differences between the samples $(t=0.77$ at $\alpha=0.05$ ). Nevertheless, there was no correlation be-

Table 4. Solea solea. Comparative statistics of the errors on reader and GDA age estimates $(N=40 ; S D$ : standard deviation). Samples were segregated into age groups

\begin{tabular}{|rrrrrr|}
\hline True age (d) & \multicolumn{2}{c}{$\begin{array}{c}\text { Reader } \\
\text { Mean error }\end{array}$} & SD & Mean error & SD \\
\hline $8-13$ & 5 & 0.60 & 0.82 & -0.20 & 1.30 \\
$14-19$ & 11 & 0.77 & 0.34 & 0.17 & 1.17 \\
$20-25$ & 9 & -0.11 & 0.86 & -0.05 & 1.63 \\
$26-30$ & 15 & 0.40 & 1.40 & 0.43 & 2.25 \\
\hline
\end{tabular}

tween errors induced by the 2 ageing methods $\left(R^{2}=\right.$ 0.03 ). Distribution of errors and their variability with increasing age were examined. Segregating the reader data into $6 \mathrm{~d}$ age classes preserves the pattern of the overall sample distribution (Figs. 5A \& 6A), but not in the subsample, presumably due to the random distribution of errors and to the size of samples ( $\mathrm{N}=170$ and 40 , respectively). This graph also shows that the GDA method was more accurate, with mean errors 3 times lower than in data obtained by the reader, except for late larvae, where similar mean errors were observed. Concerning the precision, however, the GDA method of estimating larval age was less precise by half than the reader method (Fig. 6B).

\section{DISCUSSION}

In this study, direct counts were obtained by taking into account only those increments detectable to the eye in order to avoid any interpretation in terms of daily deposition, whatever the variations of interincrement distance. The reader having previous knowledge of both larval and otolith samples (Lagardère 1989), real blind readings had to be assured by semi-automated procedures of image analysis. Image analysis requires only the positioning of a dated increment to initiate the process, as a reader initiates counts. Under these conditions, knowledge drawn from the otolith growth model may be introduced into the GDA method for integrated counts of low-contrast increments (Troadec 1991).

For validation purpose, we had to address the following questions, which involved critical examination of bias and errors (Rice 1987, Campana \& Moksness 1991, Neilson 1992). (1) Do the procedures used here actually validate the otolith technique for estimating age in sole larvae? (2) Does image analysis confirm and/or improve age estimation? Bias and errors were liable to arise from:

(1) Conditions of larval rearing and methods of otolith analysis

(2) The criteria used in interpreting the observed microstructures

(3) Any faults in the validation method.

\section{(1) Preparation and examination}

In sole larvae, the examination of unpolished sagittal otolith was feasible, using optical microscopy: the larvae had clear otoliths when their rearing temperature had been close to that in nature. Moreover, these larval sole had high survival and growth rates, resulting from optimal rearing conditions during the overall 

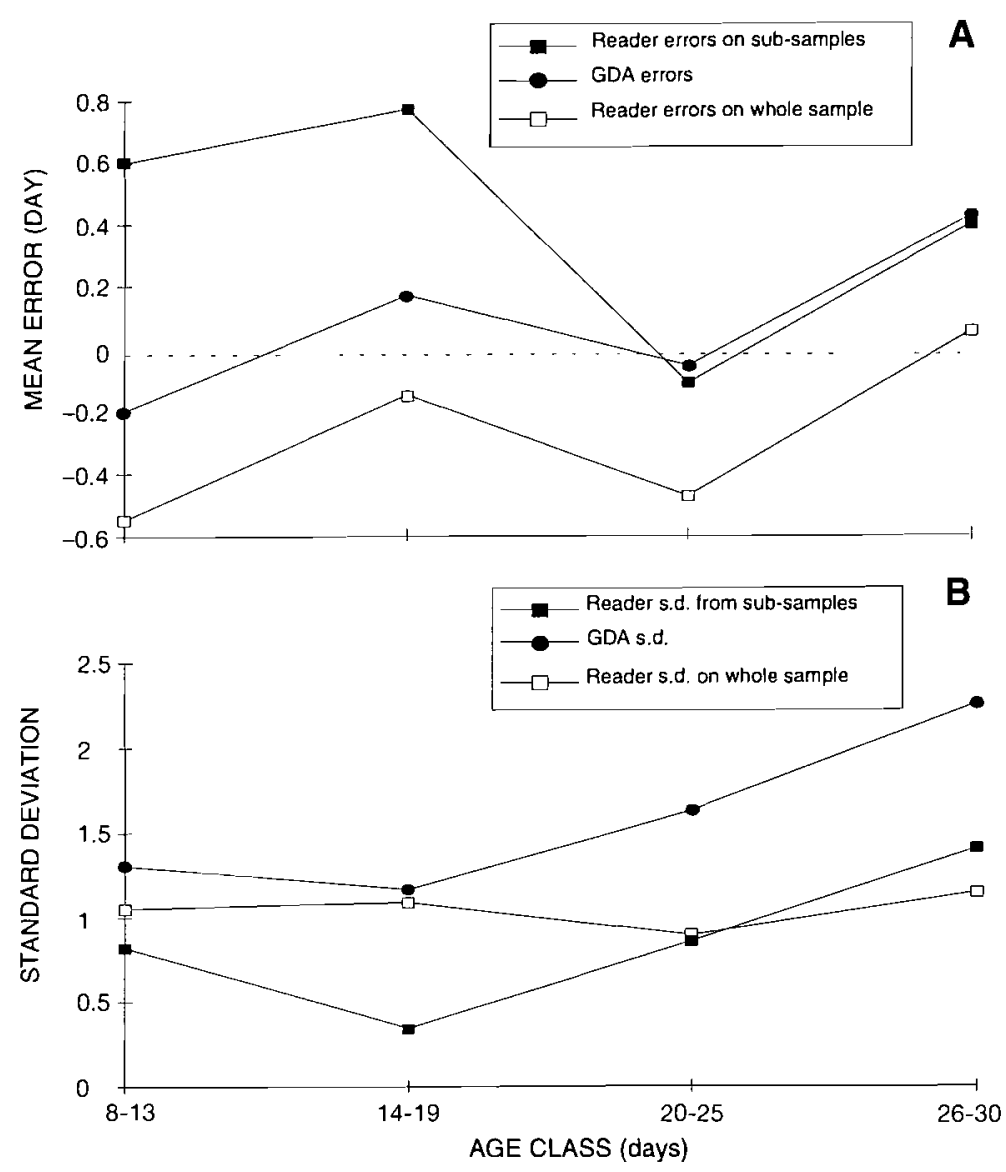

Fig. 6. Solea solea. Graph of mean error distribution versus true age classes according to sample size. (A) Comparison between reader errors (subsamples, $N=40$, and whole sample, $N=170$ ) and GDA errors. (B) Comparison between reader standard deviation (sub-samples, $\mathrm{N}=40$, and whole sample, $\mathrm{N}=170$ ) and GDA standard deviation

experiment (Lagardère 1989). Optical artefacts developed around the otolith margins because of both their crystalline structure and their lens shape. These artefacts interfered with routine readings and image analysis as well. They can mask faint increments newly deposited in the otolith margin and can even prevent GDA enumeration because of intrinsic limits in resolution. We were led to suspect: (1) missing increments, for example in the first-feeding perinuclear area (FF area); and/or (2) misinterpretation of sub-daily increments in the metamorphosis transition zone (TZ).

With the routine reading method, poorly defined increments were more often overlooked in the FF area than in the TZ. Had the latter zone been involved to the same extent, the average reading errors would not have been limited to about a $0.3 \mathrm{~d}$ underestimation. Formation of the FF area lasted only a few days, and underestimation here could involve only a few increments whose width, inferred from the otolith growth model $(\geq 0.9 \mu \mathrm{m}$ until Day 6 , and $\geq 1 \mu \mathrm{m}$ starting soon after first feeding), was always considerably more than the resolution limits. Formation of wide $(\sim 1 \mu \mathrm{m})$ increments from the beginning characterises larvae showing rapid growth and living in temperate or warm waters (e.g. $0.8 \mu \mathrm{m}$ in the ayu Plecoglossus altivelis, Tsukamoto \& Kajihara $1987 ; 0.96 \mu \mathrm{m}$ in the scianid spot Leiostomus xanthurus, Govoni et al. 1985; 0.9 to $1.8 \mu \mathrm{m}$ in the plaice Pleuronectes platessa reared at $10^{\circ} \mathrm{C}$, Karakiri \& von Westernhagen 1989). This tendency to overlook low-contrast perinuclear increments increased for unpolished larger otoliths because of concealment by additional deposits. Nevertheless, interpretation errors, involving sub-daily increments of low contrast in the metamorphosis $\mathrm{TZ}$, may have compensated for this bias up to the late larval stage beyond which sub-daily increments induced overestimated ages.

Zones of low contrast were not satisfactorily resolved by SEM techniques, both in the FF perinuclear area and in the metamorphosis TZ. Such etching failures have already been reported and explained either by morphological changes of the otoliths, making modifications to the orientation of increments in the sectioning plan (Morales-Nin 1987; see review in Neilson 1992) or by changes in the matrix content of the more etched, narrow D-zones. Morphological changes are likely to contribute to the etching characteristics of faint, multiple Dzones, as in the inner $\mathrm{TZ}$ (Lagardère et al. 1995), but not in the FF area. In both the TZ and FF areas, an impairing of the matrix content cannot be excluded due to physiological stress associated with life history transitions (Campana \& Neilson 1985). Whatever the causes may be, zones of low-contrast, poorly etched increments had appeared as component parts of sole larval otoliths, thus requiring further refinement of the techniques.

\section{(2) Interpretation and validation}

Interpretation is at the heart of investigations using otoliths (Campana \& Neilson 1985, Campana 1992). It consists in deriving biological meaning from the microstructures identified (e.g. Sogard 1991), including increments. To count daily increments, they have to be interpreted by an overall approach, permitting one to switch from a local pattern perception to a global one. 
Classical reading based on discrimination and count of increments usually fits in with a local analysis. In contrast, a global analysis, achieved by the FFT, takes into account the growth pattern structuring these basic elements. In this case, the distinction between daily and non-daily increments is based on their frequency, compared to the overall frequency growth pattern. Finally, inspection of the errors leads to an interpretation of them to try to identify their causes.

Under blind-reading conditions, there are few objective criteria to distinguish between investigators' imprecision that causes variation in the recorded signal and discontinuities in real growth. Subjective components, suspected of influencing a particular result, appear related to the examination of otoliths preceding interpretation of their microstructures (Campana \& Moksness 1991). This is especially so when daily and non-daily increments give similarly attenuated signals, and particularly when these 2 microstructures are similar in width. In order to cope with low-contrast increments and to restore the growth rhythm, either interpolation or out-of-focus inspection is accepted, within limits defined by authors (e.g. Methot 1983, Campana 1992). Interpolation is used to confirm enumeration when narrow increments give an attenuated signal (Methot 1983, Campana et al. 1987, Bailey \& Stehr 1988, Campana 1992, Toole et al. 1993). Out-offocus work on sub-daily increments, which is comparable to a low-pass Fourier filtering, can then help to discriminate them (Tsukamoto \& Kajihara 1987, Palomera et al. 1988, Campana 1992, Toole et al. 1993).

Requirement for validation of daily increments in larval otoliths of the common sole can be synthesized as follows, showing in some respects analogous features with other species.

(1) The close resemblance between otoliths in larvae reared at $12^{\circ} \mathrm{C}$ and those from the wild was met, except for differences in increment width, ascribed to the effects of more variable temperatures in the wild. We thus interpreted the principal structures in the same way, particularly the benchmarks occurring at hatching and mouth-opening (Lagardère 1989) and the zones of low-contrast increments (FF perinuclear area and metamorphosis TZ), which matched transition to exogenous feeding and to benthic living respectively. The formation of attenuated perinuclear increments during the vitelline stage is common to pelagic larvae of various temperate fish that hatch from eggs with relatively small vitelline reserves (e.g. northern anchovy Engraulis mordax, Brothers et al. 1976; flounder species such as Rhombosolea tapirina, Ammotretis rostratus, Jenkins 1987; or Pleuronectes americanus, Jearld et al. 1993). Changes in width and appearance of increments, and the deposit of accessory nuclei during metamorphosis, described on otoliths of other flatfish
(Campana 1984a, Jenkins 1987, Al-Hossaini et al. 1989, Sogard 1991, Jearld et al. 1993, Toole et al. 1993), are not limited to this order (Brothers 1984, Campana 1984b, Nishimura \& Yamada 1984, Radtke 1989, Zhang \& Runham 1992). They appear at the transition between larval and juvenile stages (Hare \& Cowen 1994). They are related to production of the sulcus (Brothers 1984, Lagardère et al. 1995) and, from a more general point of view, to the remodelling of otolith shape (Hare \& Cowen 1994).

(2) The timing of the first increment counted was known (Lagardère \& Chaumillon 1988). Jones (1986) has reviewed the information on the age at deposition of the first daily increment, which varies in different species from before hatching to after absorption of the yolk sac. Some authors refer timing to the date of first feeding (Laroche et al. 1982, Boehlert \& Yoklavitch 1985, Jenkins 1987, Rice et al. 1987, Maillet \& Checkley 1989) while Bailey \& Stehr (1988) emphasize that the 'first-feeding check... represents a change in nutritional or physiological status rather than feeding activity alone', since this mark forms also in larvae which are not fed. As pointed out by Jones \& Brothers (1987), any relationship between ontogenetic or physiological events and the initial formation of increments remains unclear, probably because several factors interact. In practice, the age when the mouth becomes functional is closely temperature-dependent, which permits dating of the benchmark matching this event. In sea bass Dicentrarchus labrax, it takes $7 \mathrm{~d}$ for the mouth to open at approximately $10^{\circ} \mathrm{C}$ (Ré et al. 1986) and in sole it takes $4 \mathrm{~d} \pm 12 \mathrm{~h}$ at $12^{\circ} \mathrm{C}$ (Lagardère 1989). In wild sole larvae, the accuracy of age at this mark, derived from pre-existing models (Fonds 1979, for the first-feeding stage), remains however subject to knowledge of ambient temperature, often varying in both time and water depth.

(3) The constant daily rate of increment deposition was consistent with a regression line between age and increment number close to $1: 1$. By using the regression line method, this assumption was not rejected (power = 0.99). Validation was then confirmed by a similar test using GDA counts, although the higher variance associated with this method imposed a lower threshold of tolerance (power $=0.68$ ), thus making the test less powerful. A tendency for the reader to underestimate daily increment numbers explains that the intercept of the regression line often significantly differs from zero, unlike in GDA estimates.

\section{(3) Evaluation of the GDA method}

In developing a pattern-recognition technique using an a priori exponential growth pattern for counting 
daily increments, the aim has been to compensate for any lack of definition in low-contrast areas by interpolated growth data. Although the GDA method may appear to behave like the human reader, comparison of errors produced by each of the 2 methods (GDA and reader counts) shows that there is no relationship between the 2 error sets $\left(R^{2}=0.03\right)$. Explanations for these differences should be sought in the examination protocols. Potential errors due to optical microscopy, documented by Campana \& Neilson (1985), Campana et al. (1987) and Neilson (1992), are discussed above and are probably related to characteristics of the examined material (unpolished specimens, including otoliths of some slow-growing larvae ${ }_{i}$ see Fig. 4). Optical artefacts have analogous effects on the quality of the image, but not on the values obtained by each method. During the GDA process, the image is digitized only in a single focal plane while the human reader has the advantage of being able to focus up and down (Campana 1992). This forces the GDA operator to choose just 1 focal plane, which cannot give as much information as the 3 -D search conducted during human inspection.

Contrary to what we had expected, the GDA method reduced the precision of counts. Reproducibility is by definition total in GDA estimates as the parameters themselves (i.e. nucleus coordinates and radial angle) are provided as data to the algorithm, even when in error themselves. The variability of the results, tested by repeating semi-automatic GDA processing, is in fact produced by the operator. To be useful in practice, robustness in the GDA method must at least counterbalance variability related to the nature of the information obtained (noise, increment appearance and edge contrast). The reproducibility of the results is conditioned thus by a balance between algorithm sensitivity and spatial variability in the data. One means of getting around this variability in the data consisted in using an averaged radial profile (Troadec \& Prouzet 1986, Troadec 1991, Welleman \& Storbeck 1995) derived by averaging the signal from several profiles. The main source of variability is due to the facts that (1) the GDA method estimates a mean number of increments using a Fourier spectrum, without counting increment-by-increment (the global estimate technique), (2) in contrast to estimates made by the reader, the perception of increments is restricted to a quadrant of $10^{\circ}$ defined by the operator, and (3) there is a lack of safeguard through a consistency test of increment estimation controlling a feedback process. Although this increment detection is an improvement on the use of single radii as profiles, it is still not as good as human perception.

Greater accuracy was obtained with the GDA method than with the reader, reflecting GDA's greater rigour and objectivity. Unlike the reader, the algorithm has neither the capacity to memorize calcified pieces (except data introduced into the program) nor learning ability. Blind-reading conditions are thus essentially fulfilled. In contrast, the operator consciously or unconsciously introduces bias (Campana \& Moksness 1991) by visualising the size and form of the otolith and inserting this information, with an associated interpretation, into the series of otoliths examined. Such action, although liable to produce errors during blind reading is unavoidable each time the reader adapts to a new situation.

Although poor definition in the FF perinuclear area and in the metamorphosis TZ remains the principal source of difficulty in image analysis, this patternrecognition technique has advanced to give more accurate estimates of low-contrast increments. These zones are interpreted by the GDA method, but still in the higher range of variability $( \pm 3 \mathrm{~d})$ which characterizes the reader's estimates. In the FF perinuclear area, insufficiency in signal is corrected for, while for increments of the metamorphosis $\mathrm{TZ}$, the correction is in the hitherto poor distinction between daily and sub-daily increments. Further, the GDA method is not sensitive to sporadic sub-daily increments inside the daily ones. Naturally, at its present stage of development, the GDA method cannot cope with multi-phased growth patterns (Troadec 1991), but it could be extended to any growth equation accepting a reciprocal function (e.g. von Bertalanffy, Gompertz). The semi-automatic procedure restricts the operator's influence to defining both the nucleus and the position corresponding to $L_{0}$ The sole restriction is that the estimate has to be made using a hypothetical growth equation, but on the other hand, no value for the mean $K$ factor need be put in (Troadec 1991, Lagardère \& Troadec 1992).

In conclusion, the hypothesis of daily increment deposition in sagittal otoliths has been verified for known-age larvae of sole reared under temperatures close to those of the Bay of Biscay. This conclusion is restricted to planktonic stages, which includes the early stage 5 (left eye on the dorsal edge) and is assumed with a variability of \pm 2 or $\pm 3 \mathrm{~d}$ depending on whether the data have been obtained by a reader or by the GDA method. Although this variability may seem high in relation to rearing duration ( $30 \mathrm{~d}$ ), it is similar to the precision found in blind-reading exercises (e.g. Rice et al. 1985, Campana \& Moksness 1991). The GDA method is still at a preliminary stage, with Fast Fourier Transformation (FFT) estimates now coming close to those made by a reader. This technique is still limited to numerical information, including information derived from growth data. The controlled structure of the model used by the GDA method and its consistent mode of operation guarantee increased ob- 
jectivity in counting and interpreting the 2 zones, the FF area and the TZ, both of low contrast. The method tends to reproduce the human visual procedure of interpreting calcified structures, combining perception of widths in well-defined increments with estimates for zones of low contrast. The GDA concept in its present form cannot be extended to every case of age estimation and future improvements to the algorithm will consist in segmentation of the signal for local detection of well-defined increments and global estimates, using interpolation for the areas of low contrast.

Acknowledgements. Thanks to J. C. Alexandre, M. Boulhic and J. Person-Le Ruyet, rearing experiments were carried out in the IFREMER Laboratory, Brest. M. J. Garet contributed to the otolith preparation for the microscope examination, and G. Chaumillon for the SEM examination. We express our gratitude to $M$. Karakiri for having so kindly shared her time and competence, to Ian Jenkinson for having improved the English text and to anonymous reviewers for their comments on the manuscript.

\section{LITERATURE CITED}

Al-Hossaini M, Liu Q, Pitcher TJ (1989) Otolith microstructure indicating growth and mortality among plaice, Pleuronectes platessa L., post-larval sub-cohorts. J Fish Biol 35(Suppl A):81-90

Al-Maghazachi SJ, Gibson R (1984) The developmental stages of larval turbot, Scophthalmus maximus L. J Exp Mar Biol Ecol 82:35-51

Amara R (1995) La sole, Solea solea (L. ), du golfe de Gascogne: métamorphose, transfert des larves vers la côte et colonisation des nourriceries. Thèse doctorat, Univ Paris 6

Amara $R$, Desaunay $Y$, Lagardère F (1994) Seasonal variation in growth of larval sole, Solea solea (L.) and consequences on the success of larval immigration. Neth J Sea Res 32: $287-298$

Amara R, Lagardère F, Desaunay Y (1993) Seasonal distribution and duration of the planktonic stage of Dover sole, Solea solea, larvae in the Bay of Biscay: an hypothesis. J Fish Biol 43(Suppl A): 17-30

Arbault S, Camus P, Le Bec C (1986) Estimation du stock de sole (Solea vulgaris, Quensel 1806) dans le golfe de Gascogne à partir de la production d'oeufs. J Appl Ichthyol 4:145-156

Bailey KM, Stehr CL (1988) The effects of feeding periodicity and ration on the rate of increment formation in otoliths of larval walleye pollock Theragra chalcogramma (Pallas). J Exp Mar Biol Ecol 122:147-161

Beamish RJ, McFarlane GA (1983) The forgotten requirement for age validation in fisheries biology. Trans Am Fish Soc 112:735-743

Boehlert GW, Yoklavitch MM (1985) Larval and juvenile growth of sablefish, Anoplopoma fimbria, as determined from otolith increments. Fish Bull US 83:475-481

Boulhic M (1991) Recherche d'indices de jeûne chez la larve de sole, Solea solea (Linnaeus, 1758): approches expérimentales et application dans le golfe de Gascogne. Thèse doctorat, Univ Bretagne Occidentale, Brest

Boulhic M, Galois R, Koutsikopoulos C, Lagardère F, PersonLe Ruyet J (1992) Etat nutritionnel, croissance et survie des stades pélagiques de la sole, Solea solea (L.) du golfe de Gascogne. Ann Inst Oceanogr 68:117-139

Brothers EB (1984) Otolith studies. In: Moser HG, Richards WJ, Cohen DM, Fahay MP, Kendall AW Jr, Richardson SL (eds) Ontogeny and systematics of fishes. Intern Symp (La Jolla). Spec Publ 1, Am Soc Ichthyol Herpetol, Allen Press, Lawrence, KS, p 50-57

Brothers EB, Mathews CP, Lasker R (1976) Daily growth increments in otoliths from larval and adult fishes. Fish Bull US 74:1-8

Campana SE (1984a) Microstructural growth patterns in the otoliths of larval and juvenile starry flounder, Platichthys stellatus. Can J Zool 62:1507-1512

Campana SE (1984b) Interactive effects of age and environmental modifiers on the production of daily growth increments in otoliths of plainfin midshipman, Porichthys notatus. Fish Bull US 82:165-177

Campana SE (1992) Measurement and interpretation of the microstructure of fish otoliths. In: Stevenson DK, Campana SE (eds) Otolith microstructure examination and analysis. Can Spec Publ Fish Aquat Sci 117:59-71

Campana SE, Gagné JA, Munro J (1987) Otolith microstructure of larval herring (Clupea harengus): image or reality? Can J Fish Aquat Sci 44:1922-1929

Campana SE, Moksness E (1991) Accuracy and precision of age and hatch date estimates from otolith microstructure examination. ICES J Mar Sci 48:303-316

Campana SE, Neilson JD (1985) Microstructure of fish otolith Can J Fish Aquat Sci 42:1014-1032

Fonds M (1979) Laboratory observations on the influence of temperature and salinity on development of the eggs and growth of the larvae of Solea solea (Pisces). Mar Ecol Prog Ser 1:91-99

Francis RICC (1995) The analysis of otolith data-a mathematician's perspective (What, precisely, is your model?) In: Secor DH, Dean JM, Campana SE (eds) Recent devel. opments in fish otolith research, Vol 19. Univ of South Carolina Press, Columbia, p 81-95

Geffen AJ (1982) Otolith ring deposition in relation to growth rate in herring (Clupea harengus) and turbot (Scophthal. mus maximus) larvae. Mar Biol 71:317-326

Geffen AJ (1992) Validation of otolith increment deposition rate. In: Stevenson DK, Campana SE (eds) Otolith microstructure examination and analysis. Can Spec Publ Fish Aquat Sci 117:101-113

Govoni JJ, Chester AJ, Hoss DE, Ortner PB (1985) An observation of episodic feeding and growth of larval Leiostomus xanthurus in the northern Gulf of Mexico. J Plankton Res $7: 137-146$

Hare JA, Cowen RK (1994) Ontogeny and otolith microstructure of bluefish Pomatomus saltatrix (Pisces: Pomatidae). Mar Biol 118:541-550

Jearld A Jr, Sass SL, Davis MF (1993) Early growth, behavior, and otolith development of the winter flounder Pleuronectes americanus. Fish Bull US 91:65-75

Jenkins GP (1987) Age and growth of co-occurring larvae of two flounder species, Rhombosolea tapirina and Ammotretis rostratus. Mar Biol 95:157-166

Jenkins GP, Davis TLO (1990) Age, growth rate, and growth trajectory determined from otolith microstructure of southern bluefin tuna Thunnus maccoyii larvae. Mar Ecol Prog Ser 63:93-104

Jones CM (1986) Determining age of larval fish with the otolith increment technique. Fish Bull US 84:91-103

Jones CM (1992) Development and application of the otolith increment technique. In: Stevenson DK, Campana SE (eds) Otolith microstructure examination and analysis. 
Can Spec Publ Fish Aquat Sci 117:1-11

Jones CM, Brothers EB (1987) Validation of the otolith increment aging technique for striped bass, Morone saxatilis, larvae reared under suboptimal feeding conditions. Fish Bull US 85:171-178

Kalish JM, Beamish RJ, Brothers EB, Casselman JM, Francis RICC, Mosegaard H, Panfili J, Prince ED, Thresher RE, Wilson CA, Wright PJ (1995) Glossary for otolith studies. In: Secor DH, Dean JM, Campana SE (eds) Recent developments in fish otolith research, Vol 19. Univ of South Carolina Press, Columbia, p 723-729

Karakiri $M$, von Westernhagen $H$ (1988) Apparatus for grinding otoliths of larval and juvenile fish for microstructure analysis. Mar Ecol Prog Ser 49:195-198

Karakiri M, von Westernhagen H (1989) Daily growth patterns in otoliths of larval and juvenile plaice (Pleuronectes platessa L.): influence of temperature, salinity, and light conditions. Rapp P-V Réun Cons Perm Int Explor Mer 191:376-382

Koutsikopoulos C (1991) Recrutement de la sole (Solea solea, L.) du golfe de Gascogne: influence de l'hydrologie et de l'hydrodynamisme. Thèse doctorat, Univ Bretagne Occidentale, Brest

Koutsikopoulos C, Fortier L, Gagné J (1991) Cross-shelf dispersion of Dover sole eggs and larvae (Solea solea) in Biscay Bay and recruitment to inshore nurseries. J Plankton Res 13:923-945

Lagardère F (1989) Influence of feeding conditions and temperature on the growth rate and otolith-increment deposition of larval Dover sole (Solea solea (L.)). Rapp P-V Réun Cons Int Explor Mer 191:390-399

Lagardère $F$, Chaumillon $G$ (1988) Influence d'une première alimentation différée sur la croissance des larves de sole, Solea vulgaris, et l'accroissement de leurs otolithes. CR Acad Sci Paris (Sér III) 306:601-607

Lagardère $F$, Chaumillon $G$, Amara $R$, Heineman G, Lago JM (1995) Examination of otolith morphology and microstructure using laser scanning microscopy (LSM). In: Secor DH, Dean JM, Campana SE (eds) Recent developments in fish otolith research, Vol 19. Univ of South Carolina Press, Columbia, p 7-26

Lagardère F, Troadec $H$ (1992) L'estimation de l'âge des larves de poissons: vers une méthode objective par utilisation d'une technique de reconnaissance de forme. In: Baglinière $\mathrm{JL}$, Castanet $\mathrm{J}$, Conand $\mathrm{F}$, Meunier $\mathrm{FJ}$ (eds) Tissus durs et âge individuel de Vertébrés. Collection Colloques et Séminaires, ORSTOM-INRA, Paris, p 79-91

Laroche JL, Richardson SL, Rosenberg AA (1982) Age and growth of a pleuronectid, Parophrys vetulus, during the pelagic larval period in Oregon coastal waters. Fish Bull US 80:93-104

Maillet GL, Checkley DM Jr (1989) Effects of starvation on the frequency of formation and width of growth increments in sagittae of laboratory-reared Atlantic menhaden Brevoortia tyrannus larvae. Fish Bull US 88:155-165

McGurk MD (1987) Age and growth of Pacific herring larvae based on length-frequency analysis and otolith ring number. Environ Biol Fish 20:33-47

Methot RD Jr (1983) Seasonal variation in survival of larval northern anchovy, Engraulis mordax, estimated from the age distribution of juveniles. Fish Bull US 81:741-750

Morales-Nin B (1987) Ultrastructure of the organic and inorganic constituents of the otoliths of the sea-bass. In: Summerfelt RC, Hall GE (eds) Age and growth of fish. The Iowa State Univ. Press, Ames, p 331-343
Neilson JD (1992) Sources of error in otolith microstructure examination. In: Stevenson DK, Campana SE (eds) Otolith microstructure examination and analysis. Can Spec Publ Fish Aquat Sci 117:115-125

Neilson JD, Geen GH (1982) Otoliths of chinook salmon (Oncorhynchus tshawytscha): daily growth increments and factors influencing their production. Can J Fish Aquat Sci 39:1340-1347

Nishimura A, Yamada J (1984) Age and growth of larval and juvenile walleye pollock, Theragra chalcogramma (Pallas), as determined by otolith daily growth increments. J Exp Mar Biol Ecol 82:191-205

Palomera I, Morales-Nin B, Lleonart J (1988) Larval growth of anchovy, Engraulis encrasicolus, in the Western Mediterranean Sea. Mar Biol 99:283-291

Radtke RL (1989) Larval fish age, growth, and body shrinkage: information available from otoliths. Can J Fish Aquat Sci 46:1884-1894

Ré P, Rosa HC, Dinis MT (1986) Daily microgrowth increments in the sagittae of Dicentrarchus labrax (L.) larvae under controlled conditions. Invest Pesq 50:397-402

Rice JA (1987) Reliability of age and growth-rate estimates derived from otolith analysis. In: Summerfelt RC, Hall GE (eds) The age and growth of fish. The Iowa State Univ. Press, Ames, p 167-176

Rice JA, Crowder LB, Binkowski FP (1985) Evaluating otolith analysis for bloater Coregonus hoyi: do otoliths ring true? Trans Am Fish Soc 114:532-539

Rice JA, Crowder LB, Holey ME (1987) Exploration of mechanisms regulating larval survival in Lake Michigan bloater: a recruitment analysis based on characteristics of individual larvae. Trans Am Fish Soc 116:703-718

Siegfried RC II, Weinstein MP (1989) Validation of daily increment deposition in the otoliths of spot (Leiostomus xanthurus). Estuaries 12:180-185

Sogard SM (1991) Interpretation of otolith microstructure in juvenile winter flounder (Pseudopleuronectes americanus): ontogenetic development, daily increment validation, and somatic growth relationships. Can J Fish Aquat Sci 48:1862-1871

Szedlmayer ST, Able KW (1992) Validation studies of daily increment formation for larval and juvenile summer flounder, Paralichthys dentatus. Can J Fish Aquat Sci 49 1856-1862

Toole CL, Markle DF, Harris PH (1993) Relationships between otolith microstructure, microchemistry, and early life history events in Dover sole, Microstomus pacificus. Fish Bull US 91:732-753

Troadec H (1991) Frequency demodulation on otolith numerical images for the automatization of fish age estimation. Aquat Living Res 4:207-219

Troadec H, Prouzet P (1986) Essai de détermination de l'âge et de la croissance du saumon atlantique (Salmo salar L.) par analyse d'image de leurs écailles. ICES, Comm Meet 1986/M:14

Tsukamoto K, Kajihara T (1987) Age determination of ayu with otolith. Nippon Suisan Gakkaishi 53:1985-1997

Welleman HC, Storbeck F (1995) Automatic aging of plaice (Pleuronectes platessa L.) otoliths by means of image analysis. In: Secor DH, Dean JM, Campana SE (eds) Recent developments in fish otolith research, Vol 19. Univ of South Carolina Press, Columbia, p 271-282

Zhang Z, Runham NW (1992) Effects of food ration and temperature level on the growth of Oreochromis niloticus (L.) and their otoliths. J Fish Biol 40:341-349 